\title{
Stripping Voltammetric Determination of Cadmium in Sea Water using a Carbon Paste Electrode Modified with Alginic Acid from Brown Algae
}

\author{
Carolina Muñoz,* Manuel Zúñiga and Verónica Arancibia \\ Facultad de Química, Pontificia Universidad Católica de Chile, 7820436, Santiago, Chile
}

\begin{abstract}
A concentração do cádmio em um meio aquoso foi determinada usando-se um elétrodo de carbono ácido-modificado de pasta de alginina. O elétrodo de trabalho foi preparado usando-se uma mistura homogênea de pó de grafite, alginina ácida (AA) e óleo mineral. A voltametria de onda quadrada com redissolução anódica (SWASV) usando-se este elétrodo modificado, mostrou uma onda anódica bem definida com pequena oxidação do AA em -0,05 V. O sinal é deslocado para um potencial menos positivo e a corrente máxima aumentou na presença do $\mathrm{Cd}^{\mathrm{II}}$. Após a otimização das condições experimentais, a corrente máxima anódica do $\mathrm{Cd}^{\mathrm{II}}$-AA mostrou ser linear com sua concentração até $c a .30 .0 \mu \mathrm{g} \mathrm{L}{ }^{-1}$, com limite de detecção de $0.9 \mu \mathrm{g} \mathrm{L}^{-1} \mathrm{em} \mathrm{pH} 2.0\left(\mathrm{HNO}_{3} \cdot \mathrm{t}_{\text {acc }}=60 \mathrm{~s}\right.$, $\left.\mathrm{E}_{\text {acc }}=-0.80 \mathrm{~V}\right)$. O método foi validado com a determinação de $\mathrm{Cd}^{\mathrm{II}}$ em água do mar sintética enriquecida (ASTM D665). O elétrodo modificado mostrou boa estabilidade e repetibilidade.
\end{abstract}

Cadmium concentration in an aqueous medium is quantified using an alginic acid-modified carbon paste electrode. The working electrode was prepared using a homogeneous mixture of graphite powder, alginic acid (AA) and mineral oil. Square wave anodic stripping voltammetry (SWASV) using this modified electrode showed one small well-resolved anodic wave for the oxidation of AA at $-0.05 \mathrm{~V}$. This signal shifts toward less positive potential and peak current increases in the presence of $\mathrm{Cd}^{\mathrm{II}}$. After optimizing the experimental conditions, the anodic peak current of Cd $\mathrm{Cd}^{\mathrm{II}}$-AA was linearly related to its concentration up to $c a .30 .0 \mu \mathrm{g} \mathrm{L}^{-1}$, with a detection limit of $0.9 \mu \mathrm{g} \mathrm{L}^{-1}$ at $\mathrm{pH} 2.0\left(\mathrm{HNO}_{3} \cdot \mathrm{t}_{\mathrm{acc}}=60 \mathrm{~s}, \mathrm{E}_{\mathrm{acc}}=-0.80 \mathrm{~V}\right)$. The method was validated by determining $\mathrm{Cd}^{\mathrm{II}}$ in spiked synthetic sea water (ASTM D665). The modified electrode showed good stability and repeatability.

Keywords: alginic acid, carbon paste electrode, cadmium, SWASV

\section{Introduction}

Alginic acid is the common name given to a family of linear polysaccharides containing 1,4-linked $\beta$-D-mannuronic acid $(\mathrm{M})$ and $\alpha$-L-guluronic acid $(\mathrm{G})$, whose pKa are 3.38 and 3.65, respectively. Alginic acid occurs in all brown algae, where it may be present in both the cell wall matrix and in the mucilage or intercellular material, and it makes up between 10 and $40 \%$ of the algae's dry weight (untreated). The ratio of mannuronic and guluronic groups and the affinity for metals ions vary with the type of algae and the part of the plant from which the polysaccharide is extracted. The presence of these G-blocks results in an enhanced selectivity for cadmium or calcium relative to monovalent ions such as sodium as well as to protons and smaller divalent ions such as magnesium.

*e-mail: cdmunozc@uc.cl
When the guluronic acid content is increased, the affinity of alginates for cations such as $\mathrm{Pb}^{2+}, \mathrm{Cu}^{2+}, \mathrm{Cd}^{2+}, \mathrm{Zn}^{2+}, \mathrm{Ca}^{2+}$, etc is higher. The major mechanisms include ionic interactions and the formation of complexes between metallic cations and groups contained in the alginic acid. Among the diverse and natural ligand availability, algae have already proved to be the most promising for heavy metal recovery. ${ }^{1-6}$

Carbon paste electrodes modified with different ligands have been used to preconcentrate the analytic target (by means of a selective chemical reaction at the surface) and then to quantify the surface-bound species using a voltammetric technique. These electrodes present some advantages, such as easy manufacture, nontoxicity, low price, wider operational potential window, and stability in various solvents. The aim of this study was to optimize stripping voltammetric procedures for the determination of cadmium using a carbon paste electrode coated with alginic acid from brown algae. 


\section{Experimental}

\section{Apparatus}

All the voltammetric measurements were carried out using a self-made carbon paste electrode modified with alginic acid as a working electrode, $\mathrm{Ag} / \mathrm{AgCl} 3 \mathrm{~mol} \mathrm{~L}^{-1}$ $\mathrm{KCl}$ as the reference electrode, and platinum wire as the auxiliary electrode. SWASV experiments were performed on a CV50W Voltammetric analyzer electrochemical system (Bioanalytical Systems. USA). The measurements were made at room temperature and dissolved oxygen was removed with bubbling Argon. For $\mathrm{pH}$ measurements an Orion $430 \mathrm{pH}$ meter was used.

\section{Reagents and solutions}

All solutions were prepared with Milli-Q water (18.2 M $\Omega$ ). Standard stock solutions of $1 \mu \mathrm{g} \mathrm{mL}-1$ of cadmium were prepared from standard cadmium $1000 \mu \mathrm{g} \mathrm{mL}^{-1}$ solution (Merck, Darmstadt, Germany). Alginic acid sodium salt from brown algae (CAS 900538-3) was obtained from Sigma. Nitric acid was obtained from Merck. Synthetic sea water (ASTM D665 Aldrich, USA) was used for validation of the method.

\section{Electrode preparation}

Modified carbon paste electrodes (MCPEs) were prepared with different alginate/graphite ratios by thoroughly homogenizing with paraffin in an agate mortar and pestle. The mixture was then packed in a cylindrical plastic tube used for insulin treatment $(1.0 \mathrm{~mL}$ and internal diameter $4 \mathrm{~mm}$ ) and connected to a copper wire to provide the electric contact. Before use the electrodes were polished with paper card and used immediately.

\section{Procedure}

$10.0 \mathrm{~mL}$ of water, $100 \mu \mathrm{L}$ of $1 \mathrm{~mol} \mathrm{~L}^{-1} \mathrm{HNO}_{3}$, and different volumes of $1.0 \mu \mathrm{g} \mathrm{mL}^{-1}$ cadmium solution were pipetted into the voltammetric cell. The air present in the solution was removed with bubbling argon (saturated with water vapor) for $5 \mathrm{~min}$ and then an accumulation potential $\left(\mathrm{E}_{\mathrm{acc}}\right)$ was applied to the freshly prepare modified carbon paste electrode while the solution was stirred $(700 \mathrm{rpm})$. After the accumulation period $\left(\mathrm{t}_{\mathrm{acc}}\right)$, the stirring was stopped, and after $10 \mathrm{~s}$ the Osteryoung square wave stripping voltammogram was recorded by applying a positive-going scan between -0.80 and $1.00 \mathrm{~V}$ with $5 \mathrm{mV}$ step amplitude, $50 \mathrm{mV}$ pulse amplitude, and a frequency of $15 \mathrm{~Hz}$. The method was validated by determining $\mathrm{Cd}^{\mathrm{II}}$ in spiked synthetic sea water (ASTM D665).

\section{Limit of detection (LOD)}

The limit of detection was calculated using the approximation of Miller and Miller ${ }^{7}$ for calibration curves. Minimum signal $\left(y_{\text {min }}\right)=a+3 S_{y / x}$, where $a=$ intercept and $S_{y / x}=$ standard deviation of the calibration curve.

\section{Results and Discussion}

\section{Effect of solution $\mathrm{pH}$}

The first step of this study was to find out the influence of $\mathrm{pH}$ on the peak current in the 2.0 to 10.0 range using Britton Robinson buffers. However, it was found that at acid $\mathrm{pH}$ adjusted with nitric acid peak current of Cd-AA had adequate values. Figure $1 \mathrm{~A}$ shows the stripping voltammogram of the carbon paste electrode (blank) in a $0.01 \mathrm{~mol} \mathrm{~L}^{-1} \mathrm{HNO}_{3}$ solution and Figure $1 \mathrm{~B}$ shows a voltammogram of the alginic acid modified carbon paste electrode (alginate/graphite powder 40/60). As shown in the figure, alginic acid (AA) has an oxidation peak at $-0.05 \mathrm{~V}$. When a trace amount of cadmium is added to the electrochemical cell (Figure 1C), the oxidation peak potential of AA shifts to less positive potential values $\left(\mathrm{P}_{1}\right)$, close to $-0.09 \mathrm{~V}$, depending on the cadmium concentration, and the peak current of AA increases greatly, while a new small and broad oxidation peak is seen at more positive potential values $\left(\mathrm{P}_{2}, 0.19 \mathrm{~V}\right)$ due to the $\mathrm{Cd}^{\mathrm{II}}$ presence.

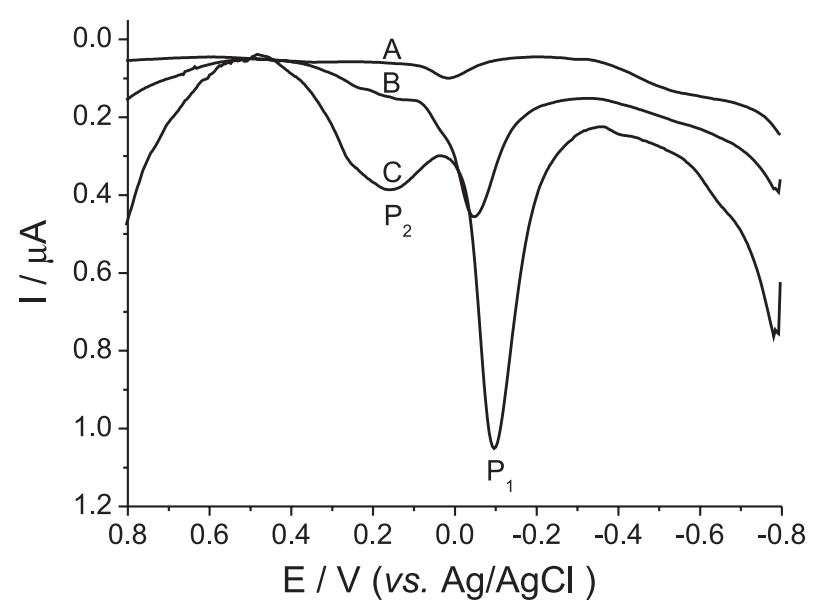

Figure 1. (A) Stripping voltammogram of carbon paste electrode; (B) carbon paste electrode modified with alginic acid 60/40 (m/m); (C) B in the presence of $4.9 \mu \mathrm{g} \mathrm{L}-1$ cadmium. $\mathrm{pH} 2\left(\mathrm{HNO}_{3}\right)$; $\mathrm{E}_{\text {acc }}=-0.80 \mathrm{~V}$; $\mathrm{t}_{\text {acc }}=60 \mathrm{~s} . \mathrm{P}_{1}:-0.09 \mathrm{~V} ; \mathrm{P}_{2}: 0.19 \mathrm{~V}$. 
Alginic acid can be oxidized to the corresponding polymeric dialdehyde acid, which undergoes hydrolysis in dilute acid. ${ }^{8}$ These measurements were made at different alginate/graphite ratios, and the best results were obtained at $40 / 60(\mathrm{~m} / \mathrm{m})$. When the amount of alginate is higher the modified electrode becomes swollen and the results obtained are not reproducible.

\section{Effect of accumulation potential}

The influence of the variation of the accumulation potential on the peak current $\left(\mathrm{P}_{1}\right.$ and $\left.\mathrm{P}_{2}\right)$, examined over the 1.00 to $-1.00 \mathrm{~V}$ range, is shown in Figure 2. While the peak current $\mathrm{P}_{2}$ is almost constant over the whole potential range, with a slight increase when an accumulation potential of $0.10 \mathrm{~V}$ was applied, the largest peak current $\mathrm{P}_{1}$ was obtained at more positive accumulation potentials $(1.00 \mathrm{~V})$ and it decreased substantially if the accumulation potential was more negative approaching $-0.20 \mathrm{~V}$, and then the peak current started increasing again. If an accumulation potential of $1.0 \mathrm{~V}$ is applied, the peak current obtained is more intense, however the signal is very broad and reproducibility is poor. A value of $-0.80 \mathrm{~V}$ was applied to later measurements and the potential was scanned in a positive direction $(-0.80$ to $1.00 \mathrm{~V})$.

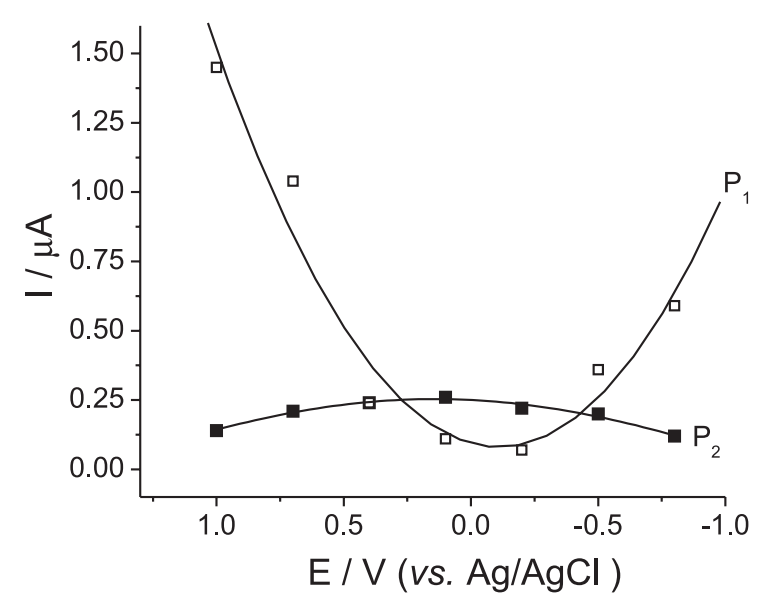

Figure 2. Effect of varying accumulation potential $(1.00$ to $-0.80 \mathrm{~V})$ on peak stripping current of $4.9 \mu \mathrm{g} \mathrm{L}^{-1}$ cadmium. $\mathrm{t}_{\text {acc }}=60 \mathrm{~s} ; \mathrm{pH} 2.0 \mathrm{P}_{1}$ : peak current to $-0.09 \mathrm{~V} ; \mathrm{P}_{2}$ : peak current to $0.19 \mathrm{~V}$.

\section{Effect of accumulation time}

As shown in Figure 3, the peak current of signal $\mathrm{P}_{2}$ is independent of accumulation time, while the peak current of signal $\mathrm{P}_{1}$ increased linearly with increasing accumulation time from 0 to $120 \mathrm{~s}$. Subsequent experiments were performed with an accumulation time of $60 \mathrm{~s}$ in order to avoid extending the time of analysis.

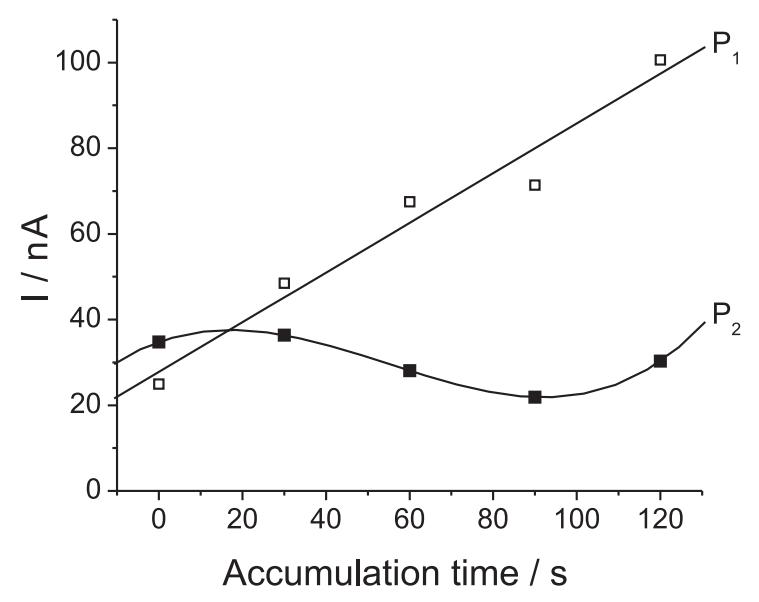

Figure 3. Effect of varying accumulation time ( 0 to $120 \mathrm{~s})$ on peak stripping current of $4.9 \mu \mathrm{g} \mathrm{L}^{-1}$ cadmium. $\mathrm{E}_{\mathrm{acc}}=-0.80 \mathrm{~V} ; \mathrm{pH} 2.0 . \mathrm{P}_{1}$ : peak current to $-0.09 \mathrm{~V} ; \mathrm{P}_{2}$ : peak current to $0.19 \mathrm{~V}$.

\section{Linear range, limit of detection, reproducibility}

The calibration graph for the determination of $\mathrm{Cd}^{\mathrm{II}}$ was obtained under the optimized conditions: 40/60 alginate/ graphite ratio, $\mathrm{pH} 2.0$ (adjusted with $\mathrm{HNO}_{3}$ solution), $\mathrm{E}_{\text {acc }}=-0.80 \mathrm{~V}$ and $\mathrm{t}_{\text {acc }}=60 \mathrm{~s}$. The peak currents $\mathrm{P}_{1}$ and $\mathrm{P}_{2}$ were proportional to the concentration of cadmium over the $0.0-40.0 \mu \mathrm{g} \mathrm{L} \mathrm{L}^{-1}$ and $0.0-30.0 \mu \mathrm{g} \mathrm{\textrm {L } ^ { - 1 }}$ range, respectively $(\mathrm{R}=0.991$ and $\mathrm{R}=0.997)$, and the detection limit obtained was $0.9 \mu \mathrm{g} \mathrm{L}^{-1}\left(\mathrm{R}=0.997, \mathrm{n}=6, \mathrm{E}_{\text {peak }}=-0.09 \mathrm{~V}\right)$. Figure 4 shows the calibration curve in Milli-Q water.

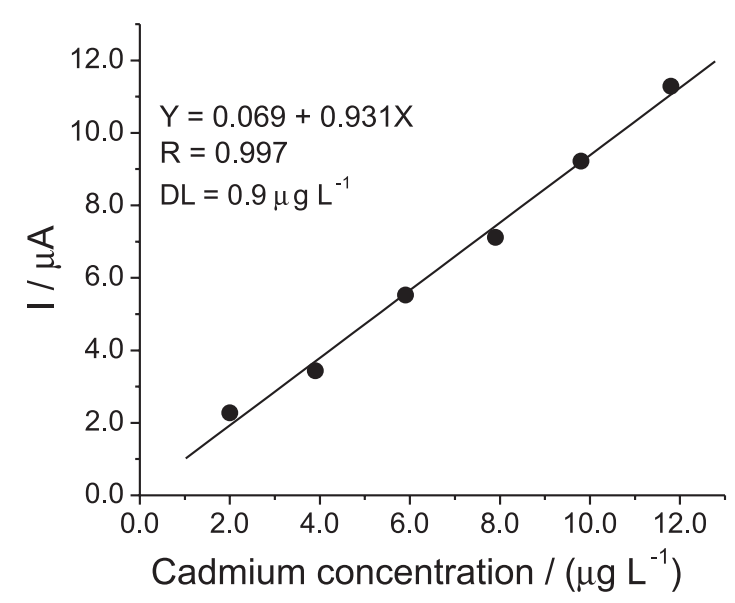

Figure 4. Effect of varying cadmium concentration $(2.0 ; 3.9 ; 5.9 ; 7.9 ; 9.8$ and $\left.11.8 \mu \mathrm{g} \mathrm{L}^{-1}\right)$ in Milli-Q water. Modified carbon paste electrode with alginic acid $(60 / 40 \mathrm{~m} / \mathrm{m}) . \mathrm{t}_{\mathrm{acc}}=60 \mathrm{~s} ; \mathrm{E}_{\mathrm{acc}}=-0.80 \mathrm{~V} ; \mathrm{pH}=2.0$.

\section{Interference studies and validation of the method}

$10.0 \mathrm{~mL}$ of synthetic sea water spiked with cadmium $\left(4.0 \mu \mathrm{g} \mathrm{L}^{-1}\right)$ was added in the electrochemical cell $\left(0.01 \mathrm{~mol} \mathrm{~L}^{-1} \mathrm{HNO}_{3}\right)$. Anodic stripping voltammograms 
were obtained and then aliquots of $\mathrm{Cd}^{\mathrm{II}}$ standard solution were added using the standard addition method. The results obtained for cadmium were $3.8 \pm 0.3 \mu \mathrm{g} \mathrm{L}^{-1}$. For the interference study an aliquot of synthetic Milli-Q water was contaminated with $\mathrm{Cd}^{\mathrm{II}}, \mathrm{Pb}^{\mathrm{II}}, \mathrm{Cu}^{\mathrm{II}}, \mathrm{Zn}^{\mathrm{II}}, \mathrm{Al}^{\mathrm{III}}$ and $\mathrm{As}^{\mathrm{III}}$ standard solution at equal concentration $\left(10.0 \mu \mathrm{g} \mathrm{L} \mathrm{L}^{-1}\right)$, and the analysis of $\mathrm{Cd}^{\mathrm{II}}$ was carried out using the standard addition method. Under these conditions $\mathrm{Cu}^{\mathrm{II}}, \mathrm{Zn}^{\mathrm{II}}, \mathrm{Al}^{\mathrm{III}}$ and $\mathrm{As}^{\mathrm{III}}$ did not show signals between -0.80 to $1.0 \mathrm{~V}$, but $\mathrm{Pb}^{\mathrm{II}}$ showed a signal at $0.26 \mathrm{~V}$. If $\mathrm{Pb}^{\mathrm{II}}$ concentration is 50 times higher than that of $\mathrm{Cd}^{\mathrm{II}}$, only one signal is seen for the two metal ions.

\section{Conclusions}

This paper shows the feasibility of determining cadmium in contaminated sea water samples using an alginate-modified carbon paste electrode. Other advantages of the proposed method are the low cost and easy preparation of the electrode. This method appears to be a promising analytical tool for the determination of cadmium in contaminated natural waters.

\section{Acknowledgements}

Financial support from the Fondo Nacional de Desarrollo Científico y Tecnológico (FONDECYT. Project $N^{\circ} 1080524$ ) and from the Comisión Nacional de Investigación Científica y Tecnológica (CONICYT) for a $\mathrm{PhD}$ scholarship is gratefully acknowledged.

\section{References}

1 Davis, T. A.; Volesky, B.; Mucci, A.; Water Res. 2003, 37, 4311.

2 Haug A.; Acta Chem. Scand. 1961, 15, 1794.

3 Haug A.; Larsen B.; Smidsrod O.; Carbohyd. Res. 1974, 32, 217.

4 Haug A.; Smidsrod O.; Acta Chem. Scand. 1965, 19, 341.

5. Davis, T.; Llanes, F.; Volesky, B.;Mucci, A.; Environ. Sci. Technol. 2003, 37, 261.

6. Fourest, E. and Volesky, B.; Environ. Sci. Technol. 1996, 30, 277.

7 Miller, J. C.; Miller, J. N.; Statistics for Analytical Chemistry, $2^{\text {nd }}$ edition, Ellis Horwood: London, 1988.

8 Lucas, H. J.; Stewart, W. T.; J. Am. Chem. Soc. 1940, 62, 1792. 